\title{
Report on the External Quality Assessment Scheme of Serologic Tests for Syphilis in Korea (2016-2017)
}

Seung-Jung Kee ${ }^{1}$, JuHyeon Shin ${ }^{1}$, HyunSeung Lee ${ }^{2}$, and SangGon Lee ${ }^{3}$

${ }^{1}$ Department of Laboratory Medicine, Chonnam National University Hospital, Gwangju; ${ }^{2}$ Department of Laboratory Medicine, Chonbuk National University Hospital, Jeonju; ${ }^{3}$ Department of Laboratory Medicine, Green Cross Laboratories, Yongin, Korea

Corresponding author: Seung-Jung Kee Department of Laboratory Medicine, Chonnam National University Hospital, Chonnam National University Medical School, 42 Jebong-ro, Dong-gu, Gwangju 61469, Korea Tel: +82-62-220-5343 Fax: +82-62-224-2518 E-mail: sjkee@jnu.ac.kr

\begin{abstract}
The 2016-2017 surveys on the external quality assessment scheme for serologic tests for syphilis in Korea were conducted by the Korean Association of External Quality Assessment Service. Proficiency testing (PT) panels consisting of three pooled serum samples were shipped to 430 and 432 laboratories participating in the program in the 1st and 2nd trials of 2016 and 465 and 503 laboratories in the 1st and 2nd trials of 2017, respectively. The rates of returning results were $94.2 \%$ and $50.2 \%$ for non-treponemal and treponemal tests, respectively, in the 1 st trial of $2016 ; 94.7 \%$ and $49.5 \%$ in the 2 nd trial of $2016 ; 94.2 \%$ and $49.5 \%$ in the 1 st trial of 2017 ; and $92.8 \%$ and $48.7 \%$ in the 2 nd trial of 2017 , respectively. The most commonly used methods for non-treponemal tests were rapid plasma reagin (RPR) card test, followed by RPR turbidoimmunoassay and venereal disease research laboratory tests. The most commonly used methods for treponemal tests were Treponema pallidum particle agglutination, followed by immunochromatographic assay, Treponema pallidum latex agglutination, chemiluminescence immunoassay, and fluorescent treponemal antibodyabsorption. The accuracy rates of the $2017 \mathrm{PT}$ for non-treponemal and treponemal tests were $92.5 \%-99.8 \%$ and $93.3 \%-100.0 \%$, respectively, which were significantly lower compared to the $98.4 \%-100.0 \%$ and $97.0 \%-100.0 \%$ in 2016 . A possible explanation for the lower accuracy rates in the 2017 PT survey is the matrix effect caused by pooling multiple individual serum samples. These data suggest that pooling of serum samples obtained from a small number of donors may help avoid the matrix effect affecting standard materials used for syphilis serology PT.
\end{abstract}

(J Lab Med Qual Assur 2018;40:182-187)

Key Words: External quality assessment, Proficiency testing, Serology, Syphilis

\section{서론}

대한임상검사정도관리협회는 신빙도조사사업에 참여하는 기관을 대상으로 연 2회 감염성 세균항원항체검사 프로그램의 유일한 항목인 매독혈청검사에 대한 신빙도조사를 실시하고 있다. 감염성 세균항원항체검사 프로그램은 크게 비트레포네 마검사(non-treponemal test)와 트레포네마검사(treponemal test)의 2항목으로 구성되어 있다. 대한임상검사정도관리협회 가 새롭게 사업프로그램을 구성하고 차세대 신빙도조사사업 을 착수한 2016년 이래 2017년까지 2년간 4차에 걸쳐 감염성
세균항원항체검사 신빙도조사를 실시하였고, 기관별 검사방 법에 대한 결과를 종합적으로 분석하고, 질 관리수준, 문제점 분석, 향상방안 등을 제시하고자 하였다.

\section{재료 및 방법}

\section{1. 신빙도조사 방법}

2016년부터 2017년까지 총 4회에 걸쳐 감염성 세균항원항 체검사 프로그램의 비트레포네마 및 트레포네마 매독혈청검 사 2항목에 대한 신빙도조사를 실시하였다. 2016년 1차 신빙 


\section{Journal of LABORATORY MEDICINE and QUALITY ASSURANCE}

Seung-Jung Kee et al • Report (2016-2017) on Syphilis Serology EQA

도조사에 총 3검체(IB-16-01, IB-16-02, IB-16-03)를 430기 관에, 2차 신빙도조사에 총 3검체(IB-16-04, IB-16-05, IB16-06)를 432기관에 각각 2016년 6월과 10월에 발송하였다. 2017년 1차 신빙도조사에 총 3검체(IB-17-01, IB-17-02, IB17-03)를 465기관에, 2차 신빙도조사에 총 3검체(IB-17-04, $\mathrm{IB}-17-05, \mathrm{IB}-17-06)$ 를 503기관에 각각 2017년 5월과 10월 에 발송하였다. 모든 신청과 결과입력, 결과판정 등은 대한임 상검사정도관리협회 홈페이지에 구축된 신빙도조사 프로그램 (http://eqas.keqas.org/)을 이용하였다.

\section{2. 관리물질 제조}

2016-2017년 감염성 세균항원항체검사 신빙도조사사업을 위한 정도관리물질은 녹십자의료재단에서 인체유래물 연구 심의위원회의 승인(GCRL-2016-04) 후 다음과 같이 제조하 였다. 녹십자의료재단에서 rapid plasma reagin (RPR) 혼탁 면역검사(turbidoimmunoassay, TIA), 트레포네마라텍스응 집검사(Treponema pallidum latex agglutination, TPLA), 형광트레포네마항체흡수검사(fluorescent treponemal antibody-absorption, FTA-ABS)의 항목이 의뢰되어 결과 가 음성 및 양성으로 보고된 잔여 검체를 대상으로 제조사가 제시한 시약설명서를 근거로 검체 안정성이 유지되는 기간 내 의 잔여 검체를 사용하였다. 단, 각각의 음성 및 양성 검체는 hepatitis B surface antigen, hepatitis C virus antibody, human immunodeficiency virus antigen/antibody 분석결
과 음성인 검체만 제조대상으로 선정하였다. 수집된 검체는 $3,000 \mathrm{rpm}, 4^{\circ} \mathrm{C}, 15$ 분간 원심분리를 실시하여 상층의 불순물 및 부유물을 제거하였다. 원심한 검체는 상층액과 침전된 하 층을 제거하여 다른 용기로 검체를 옮긴 후 교반기를 이용하 여 $150 \mathrm{rpm}, 4^{\circ} \mathrm{C}, 18$ 시간 진탕하여 균질한 검체를 제조하였 다. 균질화 과정을 거쳐 제작된 pooled serum 시료는 $0.22 \mu \mathrm{M}$ Durapore Millipore를 이용하여 잔여 불순물을 제거하여 용기 에 분주하였다. 각 시료의 제조된 물질을 식별하기 위해 대한 임상검사정도관리협회로부터 받은 물질명대로 각 용기에 라 벨을 부착하였으며, 운반 시 외부손상 및 파손 충격으로부터 보호하며 이물질의 혼입과 오염을 방지하기 위해 포장작업을 실시하였다. 제조가 완료된 검체는 $-85^{\circ} \mathrm{C}$ 에서 $-70^{\circ} \mathrm{C}$ 의 초저 온냉동고에 보관 후 운송일정에 맞춰 냉동상태로 대한임상검 사정도관리협회로 배송, 제조물질을 인계하였으며, 인계 시 인 수인계증을 통해 물질의 수량 및 상태를 재확인하였다. 제조된 정도관리물질의 평가시험에 사용된 검사, 시약, 장비는 Table 1 에 기술하였다.

\section{3. 결과 판정 및 해석}

정성 결과는 의도된 결과와 일치하는 경우 'acceptable' 하다고 판정하였다. 이 기준에 맞지 않은 답을 하거나 응답 하지 않은 경우 'unacceptable'로 판정하였다. 정성 결과가 consensus(전체 기관의 결과값의 $80 \%$ 일치)에 미달하면 판 정을 보류하거나 제외하였다. Venereal Disease Research

Table 1. Tests used for checking homogeneity and stability of control specimens for syphilis serology proficiency

\begin{tabular}{clll}
\hline Serologic tests for syphilis & Methods & Instruments & Reagents \\
\hline Non-treponemal & VDRL test & Manual & BD VDRL Antigen for Syphilis Serology \\
RPR TIA test & AU5400 & Mediace RPR \\
RPR card test & Manual & Asan RPR Card Test \\
& & & IVD Labslide RPR \\
Treponemal & TPPA test & BD Macro-Vue RPR Card Test \\
& TPLA* test & AUnual & SERODIA-TPPA \\
& ICA test & Manual & Mediace TPLA \\
& & SD Syphilis 3.0 Kit \\
& & Asan Easy Test Syphilis \\
& & Humasis Syphilis Card \\
\end{tabular}

The instrument used was from the following company: AU5400 (Beckman Coulter Inc., Brea, CA, USA).

Abbreviations: VDRL, Venereal Disease Research Laboratory test; RPR, rapid plasma reagin test; TIA, turbidoimmunoassay test; TPPA, Treponema pallidum particle agglutination test; TPLA, Treponema pallidum latex agglutination test; ICA, immunochromatographic assay test.

${ }^{\star}$ TPLA is one of the automated treponemal tests based on TIA. 
Laboratory (VDRL) 역가(titer) 결과는 최빈수 titer \pm 1 titer 의 범위(전체 기관의 결과값의 $80 \%$ 이상 포함) 내에 있는 경 우 'acceptable' 하다고 판정하였다. 그 titer 범위 외에 있는 경 우나 정성 결과와 일치하지 않으면 “unacceptable”로 판정하 였다.

\section{결과}

\section{1. 참여기관 수 및 결과 회신율}

최소 1 항목 이상 감염성 세균항원항체검사 신빙도조사에 참여한 기관 수와 각 항목별 검사결과 회신율을 조사하였다. 2016년 1차는 총 430기관이 신빙도조사에 참여하여 405기관 (94.2\%)과 216기관(50.2\%)이 각각 비트레포네마검사와 트 레포네마검사 결과를 회신하였다. 2016년 2차는 총 432기관 이 참여하여 409기관(94.7\%)과 214기관(49.5\%)이 각각 비 트레포네마검사와 트레포네마검사 결과를 회신하였다. 2017 년 1차는 총 465기관이 참여하여 438기관(94.2\%)과 230기 관(49.5\%)이 각각 비트레포네마검사와 트레포네마검사 결과 를 회신하였다. 2017년 2차는 총 503기관이 참여하여 467기관 (92.8\%)과 245기관(48.7\%)이 각각 비트레포네마검사와 트레 포네마검사 결과를 회신하였다(Table 2).

\section{2. 검사방법}

신빙도조사에 참여한 기관들의 비트레포네마검사와 트레포 네마검사 항목별 검사방법의 사용률은 공통결과보고서와 개 별결과보고서를 참조하여 회신한 모든 검사방법 총합을 기준 으로 하여 분석하였다. 2016년 1차와 2차, 2017년 1차와 2차
신빙도조사에서 비트레포네마검사법 중 VDRL 사용률은 각 각 $10.0 \%, 9.4 \%, 9.7 \%, 9.4 \%$ 였다. RPR card 수기법 사용 률은 각각 $50.8 \%, 51.8 \%, 50.3 \%, 50.7 \%$ 였고, RPR TIA 자 동화법 사용률은 각각 $29.5 \%, 31.4 \%, 36.4 \%, 36.1 \%$ 였다. 방법을 모르는 RPR unknown 사용률도 각각 $9.8 \%, 7.4 \%$, $3.5 \%, 3.9 \%$ 였다(Table 3). 2016년 1차와 2차, 2017년 1차 와 2차 신빙도조사에서 트레포네마검사법 중 $\mathrm{FTA}-\mathrm{ABS}$ 사 용률은 각각 $5.0 \%, 5.1 \%, 4.3 \%, 4.5 \%$ 였다. 트레포네마입 자응집검사(Treponema pallidum particle agglutination, $\mathrm{TPPA}$ ) 수기법 사용률은 각각 $43.9 \%, 43.5 \%, 40.3 \%, 38.7 \%$ 였고, TPLA TIA 자동화법 사용률은 각각 $17.2 \%, 16.9 \%$, $17.4 \%, 17.1 \%$ 였다. 화학발광면역검사(chemiluminescence immunoassay, CLIA) 자동화법 사용률은 각각 $15.1 \%$, $14.8 \%, 16.2 \%, 15.2 \%$ 였고, 면역크로마토그래피검사 (immunochromatographic assay, ICA) 사용률은 각각 $13.8 \%, 16.0 \%, 18.6 \%, 21.6 \%$ 였다. 방법을 모르는 트레포네 마검사 사용률도 각각 $5.0 \%, 3.8 \%, 3.2 \%, 3.0 \%$ 였다(Table 3).

\section{3. 항목별 결과분석}

\section{1) 비트레포네마검사}

2016년 1차 신빙도조사사업에 2개의 음성 검체(IB- $16-01$, IB-16-02)와 1개의 양성 검체(IB-16-03)를, 2차 사업에 2개 의 음성 검체(IB- $16-04, \mathrm{IB}-16-05)$ 와 1 개의 양성 검체(IB-1606)를 각각 이용하였다. 각 검체당 회신한 모든 비트레포네마 검사 결과의 총합을 기준으로 하여 분석하였다. IB-16-01 검

Table 2. Reporting rate of laboratories participating in the second trial of syphilis serology proficiency testing in 2017

\begin{tabular}{|c|c|c|c|}
\hline \multirow[t]{2}{*}{ Type of laboratory } & \multirow{2}{*}{$\begin{array}{l}\text { No. of participating } \\
\text { laboratories }\end{array}$} & \multicolumn{2}{|c|}{$\begin{array}{l}\text { No. of labs returning results in the second trial of syphilis } \\
\text { serology proficiency testing in } 2017\end{array}$} \\
\hline & & Non-treponemal tests & Treponemal tests \\
\hline Tertiary hospital & 43 & $43(100.0)$ & $37(86.0)$ \\
\hline General hospital & 252 & $248(98.4)$ & $113(44.8)$ \\
\hline Small hospital & 100 & $91(91.0)$ & $20(20.0)$ \\
\hline Physician's clinic & 51 & $33(64.7)$ & $30(58.8)$ \\
\hline Military hospital & 12 & $9(75.0)$ & $6(50.0)$ \\
\hline Public health center & 20 & $20(100.0)$ & $20(100.0)$ \\
\hline Independent medical laboratory & 19 & $19(100.0)$ & $14(73.7)$ \\
\hline Blood laboratory center & 3 & $3(100.0)$ & $3(100.0)$ \\
\hline Research institute & 3 & $1(33.3)$ & $2(66.7)$ \\
\hline Total & 503 & $467(92.8)$ & $245(48.7)$ \\
\hline
\end{tabular}

Values are presented as number (\%). 
Journal of LABORATORY MEDICINE and QUALITY ASSURANCE

Seung-Jung Kee et al • Report (2016-2017) on Syphilis Serology EQA

Table 3. Trend of methods used in syphilis serology proficiency testing in 2016-2017

\begin{tabular}{|c|c|c|c|c|c|}
\hline \multirow{2}{*}{ Serologic tests for syphilis } & \multirow{2}{*}{ Methods } & \multicolumn{2}{|c|}{2016} & \multicolumn{2}{|c|}{2017} \\
\hline & & 1st trial & 2nd trial & 1st trial & 2nd trial \\
\hline \multirow[t]{5}{*}{ Non-treponemal } & VDRL test & $44(10.0)$ & $42(9.4)$ & $47(9.7)$ & $48(9.4)$ \\
\hline & RPR card test & $224(50.8)$ & $231(51.8)$ & $243(50.3)$ & $260(50.7)$ \\
\hline & RPR TIA test & $130(29.5)$ & $140(31.4)$ & $176(36.4)$ & $185(36.1)$ \\
\hline & RPR unknown & $43(9.8)$ & $33(7.4)$ & $17(3.5)$ & $20(3.9)$ \\
\hline & Total & $441(100.0)$ & $446(100.0)$ & $483(100.0)$ & $513(100.0)$ \\
\hline \multirow[t]{7}{*}{ Treponemal } & FTA-ABS test & $12(5.0)$ & $12(5.1)$ & $11(4.3)$ & $12(4.5)$ \\
\hline & TPPA test & $105(43.9)$ & $103(43.5)$ & $102(40.3)$ & $104(38.7)$ \\
\hline & TPLA $^{\star}$ test & $41(17.2)$ & 40 (16.9) & $44(17.4)$ & $46(17.1)$ \\
\hline & CLIA test & $36(15.1)$ & $35(14.8)$ & $41(16.2)$ & $41(15.2)$ \\
\hline & ICA test & $33(13.8)$ & $38(16.0)$ & $47(18.6)$ & $58(21.6)$ \\
\hline & Unknown & $12(5.0)$ & $9(3.8)$ & $8(3.2)$ & $8(3.0)$ \\
\hline & Total & $239(100.0)$ & $237(100.0)$ & $253(100.0)$ & $269(100.0)$ \\
\hline
\end{tabular}

Values are presented as number (\%).

Abbreviations: VDRL, Venereal Disease Research Laboratory test; RPR, rapid plasma reagin test; TIA, turbidoimmunoassay test; FTA-ABS, fluorescent treponemal antibody-absorption test; TPPA, Treponema pallidum particle agglutination test; TPLA, Treponema pallidum latex agglutination test; CLIA, chemiluminescence immunoassay test; ICA, immunochromatographic assay test.

*TPLA is one of the automated treponemal tests based on TIA.

체에 대한 비트레포네마검사 총 441예 중 434예가 음성, IB16-02 검체는 총 441예 중 438예가 음성, IB-16-03 검체는 총 441예 중 440예가 양성으로, 각각 $98.4 \%, 99.3 \%, 99.8 \%$ 의 정답률을 보였다. IB-16-04 검체에 대한 비트레포네마검사 총 446예 중 445예가 음성, IB-16-05 검체는 총 446예 중 441예 가 음성, $\mathrm{IB}-16-06$ 검체는 총 446예 중 446예가 양성으로, 각 각 $99.8 \%, 98.9 \%, 100.0 \%$ 의 정답률을 보였다(Table 4).

2017년 1차 신빙도조사사업에 2개의 음성 검체(IB-17-02, IB-17-03)와 1개의 양성 검체(IB-17-01)를, 2차 사업에 2개 의 음성 검체(IB-17-04, IB-17-05)와 1개의 양성 검체(IB-1706)를 각각 이용하였다. 각 검체당 회신한 모든 비트레포네마 검사 결과의 총합을 기준으로 하여 분석하였다. IB-17-01 검 체에 대한 비트레포네마검사 총 483예 중 481예가 양성, IB$17-02$ 검체는 총 483예 중 447예가 음성, IB-17-03 검체는 총 483예 중 453예가 음성으로, 각각 $99.6 \%, 92.5 \%, 93.8 \%$ 의 정답률을 보였다. IB-17-04 검체에 대한 비트레포네마검사 총 513예 중 506예가 음성, IB-17-05 검체는 총 513예 중 511예 가 음성, IB-17-06 검체는 총 512예 중 511예가 양성으로, 각 각 $98.6 \%, 99.6 \%, 99.8 \%$ 의 정답률을 보였다(Table 5 ).

\section{2) 트레포네마검사}

2016년 1차와 2차 신빙도조사사업의 각 검체당 회신한 모 든 트레포네마검사 결과의 총합을 기준으로 하여 분석하였다.
IB-16-01 검체에 대한 트레포네마검사 총 239예 중 233예가 음성, IB-16-02 검체는 총 239예 중 234예가 음성, IB-16-03 검체는 총 239예 중 239예가 양성으로, 각각 $97.5 \%, 97.9 \%$, $100.0 \%$ 의 정답률을 보였다. IB-16-04 검체에 대한 트레포네 마검사 총 236예 중 233예가 음성, IB- $16-05$ 검체는 총 235예 중 228예가 음성, IB-16-06 검체는 총 237예 중 237예가 양성 으로, 각각 $98.7 \%, 97.0 \%, 100.0 \%$ 의 정답률을 보였다(Table 4).

2017년 1차와 2차 신빙도조사사업의 각 검체당 회신한 모 든 트레포네마검사 결과의 총합을 기준으로 하여 분석하였다. IB-17-01 검체에 대한 트레포네마검사 총 253예 중 253예가 양성, IB-17-02 검체는 총 252예 중 237예가 음성, IB-17-03 검체는 총 252예 중 235 예가 음성으로, 각각 $100.0 \%, 94.0 \%$, $93.3 \%$ 의 정답률을 보였다. IB-17-04 검체에 대한 트레포네 마검사 총 269예 중 268예가 음성, IB-17-05 검체는 총 269예 중 268예가 음성, IB-17-06 검체는 총 269예 중 268예가 양성 으로, 각각 $99.6 \%, 99.6 \%, 99.6 \%$ 의 정답률을 보였다(Table 5).

\section{고찰}

2016년 차세대 신빙도조사사업 시행에 따라 2016년부터 감 염성 세균항원항체검사 프로그램은 그 이전과 다르게 진행하 
Table 4. Results of syphilis serology proficiency testing using control specimens in 2016

\begin{tabular}{|c|c|c|c|c|c|c|c|c|c|c|c|c|c|c|c|c|c|c|c|}
\hline \multirow{2}{*}{$\begin{array}{l}\text { Serologic tests for } \\
\text { syphilis }\end{array}$} & \multirow{2}{*}{ Methods } & \multicolumn{3}{|c|}{ IB-16-01 } & \multicolumn{3}{|c|}{ IB-16-02 } & \multicolumn{3}{|c|}{ IB-16-03 } & \multicolumn{3}{|c|}{ IB-16-04 } & \multicolumn{3}{|c|}{ IB-16-05 } & \multicolumn{3}{|c|}{ IB-16-06 } \\
\hline & & $\mathrm{N}$ & $\mathrm{R}$ & $\mathrm{T}$ & $\mathrm{N}$ & $\mathrm{R}$ & $\mathrm{T}$ & $\mathrm{N}$ & $\mathrm{R}$ & $\mathrm{T}$ & $\mathrm{N}$ & $\mathrm{R}$ & $\mathrm{T}$ & $\mathrm{N}$ & $\mathrm{R}$ & $\mathrm{T}$ & $\mathrm{N}$ & $\mathbf{R}$ & $\mathrm{T}$ \\
\hline \multirow[t]{5}{*}{ Non-treponemal } & VDRL test & 43 & 1 & 44 & 42 & 2 & 44 & 0 & 44 & 44 & 42 & 0 & 42 & 42 & 0 & 42 & 0 & 42 & 42 \\
\hline & RPR card test & 223 & 1 & 224 & 223 & 1 & 224 & 0 & 224 & 224 & 231 & 0 & 231 & 231 & 0 & 231 & 0 & 231 & 231 \\
\hline & RPR TIA test & 127 & 3 & 130 & 130 & 0 & 130 & 1 & 129 & 130 & 139 & 1 & 140 & 136 & 4 & 140 & 0 & 140 & 140 \\
\hline & RPR unknown & 41 & 2 & 43 & 43 & 0 & 43 & 0 & 43 & 43 & 33 & 0 & 33 & 32 & 1 & 33 & 0 & 33 & 33 \\
\hline & Total & 434 & 7 & 441 & 438 & 3 & 441 & 1 & 440 & 441 & 445 & 1 & 446 & 441 & 5 & 446 & 0 & 446 & 446 \\
\hline \multirow[t]{7}{*}{ Treponemal } & FTA-ABS test & 12 & 0 & 12 & 12 & 0 & 12 & 0 & 12 & 12 & 12 & 0 & 12 & 12 & 0 & 12 & 0 & 12 & 12 \\
\hline & TPPA test & 105 & 0 & 105 & 105 & 0 & 105 & 0 & 105 & 105 & 102 & 0 & 102 & 102 & 0 & 102 & 0 & 103 & 103 \\
\hline & TPLA $^{\star}$ test & 41 & 0 & 41 & 41 & 0 & 41 & 0 & 41 & 41 & 40 & 0 & 40 & 40 & 0 & 40 & 0 & 40 & 40 \\
\hline & CLIA test & 30 & 6 & 36 & 31 & 5 & 36 & 0 & 36 & 36 & 33 & 2 & 35 & 28 & 6 & 34 & 0 & 35 & 35 \\
\hline & ICA test & 33 & 0 & 33 & 33 & 0 & 33 & 0 & 33 & 33 & 37 & 1 & 38 & 37 & 1 & 38 & 0 & 38 & 38 \\
\hline & Unknown & 12 & 0 & 12 & 12 & 0 & 12 & 0 & 12 & 12 & 9 & 0 & 9 & 9 & 0 & 9 & 0 & 9 & 9 \\
\hline & Total & 233 & 6 & 239 & 234 & 5 & 239 & 0 & 239 & 239 & 233 & 3 & 236 & 228 & 7 & 235 & 0 & 237 & 237 \\
\hline
\end{tabular}

Abbreviations: N, non-reactive; R, reactive; T, total; VDRL, Venereal Disease Research Laboratory test; RPR, rapid plasma reagin test; TIA, turbidoimmunoassay test; FTA-ABS, fluorescent treponemal antibody-absorption test; TPPA, Treponema pallidum particle agglutination test; TPLA, Treponema pallidum latex agglutination test; CLIA, chemiluminescence immunoassay test; ICA, immunochromatographic assay test. ${ }^{*}$ TPLA is one of the automated treponemal tests based on TIA.

Table 5. Results of syphilis serology proficiency testing using control specimens in 2017

\begin{tabular}{|c|c|c|c|c|c|c|c|c|c|c|c|c|c|c|c|c|c|c|c|}
\hline \multirow{2}{*}{$\begin{array}{c}\text { Serologic tests for } \\
\text { syphilis }\end{array}$} & \multirow{2}{*}{ Methods } & \multicolumn{3}{|c|}{ IB-17-01 } & \multicolumn{3}{|c|}{ IB-17-02 } & \multicolumn{3}{|c|}{ IB-17-03 } & \multicolumn{3}{|c|}{ IB-17-04 } & \multicolumn{3}{|c|}{ IB-17-05 } & \multicolumn{3}{|c|}{ IB-17-06 } \\
\hline & & $\mathrm{N}$ & $\mathbf{R}$ & $\mathrm{T}$ & $\mathrm{N}$ & $\mathrm{R}$ & $\mathrm{T}$ & $\mathrm{N}$ & $\mathbf{R}$ & $\mathrm{T}$ & $\mathbf{N}$ & $\mathbf{R}$ & $\mathrm{T}$ & $\mathrm{N}$ & $\mathrm{R}$ & $\mathrm{T}$ & $\mathrm{N}$ & $\mathbf{R}$ & $\mathrm{T}$ \\
\hline \multirow[t]{5}{*}{ Non-treponemal } & VDRL test & 0 & 47 & 47 & 47 & 0 & 47 & 47 & 0 & 47 & 47 & 1 & 48 & 48 & 0 & 48 & 0 & 48 & 48 \\
\hline & RPR card test & 2 & 241 & 243 & 242 & 1 & 243 & 239 & 4 & 243 & 260 & 0 & 260 & 259 & 1 & 260 & 1 & 258 & 259 \\
\hline & RPR TIA test & 0 & 176 & 176 & 141 & 35 & 176 & 150 & 26 & 176 & 179 & 6 & 185 & 184 & 1 & 185 & 0 & 185 & 185 \\
\hline & RPR unknown & 0 & 17 & 17 & 17 & 0 & 17 & 17 & 0 & 17 & 20 & 0 & 20 & 20 & 0 & 20 & 0 & 20 & 20 \\
\hline & Total & 2 & 481 & 483 & 447 & 36 & 483 & 453 & 30 & 483 & 506 & 7 & 513 & 511 & 2 & 513 & 1 & 511 & 512 \\
\hline \multirow[t]{7}{*}{ Treponemal } & FTA-ABS test & 0 & 11 & 11 & 11 & 0 & 11 & 11 & 0 & 11 & 12 & 0 & 12 & 12 & 0 & 12 & 0 & 12 & 12 \\
\hline & TPPA test & 0 & 102 & 102 & 100 & 2 & 102 & 99 & 3 & 102 & 104 & 0 & 104 & 104 & 0 & 104 & 0 & 104 & 104 \\
\hline & TPLA* test $^{*}$ & 0 & 44 & 44 & 44 & 0 & 44 & 43 & 1 & 44 & 46 & 0 & 46 & 46 & 0 & 46 & 0 & 46 & 46 \\
\hline & CLIA test & 0 & 41 & 41 & 28 & 12 & 40 & 29 & 11 & 40 & 41 & 0 & 41 & 41 & 0 & 41 & 0 & 41 & 41 \\
\hline & ICA test & 0 & 47 & 47 & 46 & 1 & 47 & 45 & 2 & 47 & 57 & 1 & 58 & 58 & 0 & 58 & 1 & 57 & 58 \\
\hline & Unknown & 0 & 8 & 8 & 8 & 0 & 8 & 8 & 0 & 8 & 8 & 0 & 8 & 7 & 1 & 8 & 0 & 8 & 8 \\
\hline & Total & 0 & 253 & 253 & 237 & 15 & 252 & 235 & 17 & 252 & 268 & 1 & 269 & 268 & 1 & 269 & 1 & 268 & 269 \\
\hline
\end{tabular}

Abbreviations: N, non-reactive; R, reactive; T, total; VDRL, Venereal Disease Research Laboratory test; RPR, rapid plasma reagin test; TIA, turbidoimmunoassay test; FTA-ABS, fluorescent treponemal antibody-absorption test; TPPA, Treponema pallidum particle agglutination test; TPLA, Treponema pallidum latex agglutination test; CLIA, chemiluminescence immunoassay test; ICA, immunochromatographic assay test. ${ }^{*}$ TPLA is one of the automated treponemal tests based on TIA.

였다. 2016년 이전 신빙도조사사업에서 매 회차마다 바이러스 항원항체검사용 자가제조물질 2개, 매독혈청검사용 자가제조 물질 1개로 총 3개씩 발송하였으나, 2016년 이후 사업부터는 매독혈청검사 항목을 단독으로 분리하여 매 회차당 2개의 자
가제조물질을 추가하여 총 3개의 정도관리물질을 발송하는 감 염성 세균항원항체검사 프로그램으로 변경하였다.

2016년 감염성 세균항원항체검사 1차와 2차 신빙도조사사 업에 각각 430기관과 432기관이 참여하였고, 2017년 1차와 2 
Seung-Jung Kee et al • Report (2016-2017) on Syphilis Serology EQA

차 사업에 465기관과 503 기관이 참여하여 2016년 같은 회차 에 비해 각각 35 기관(8.1\%)과 71 기관(16.4\%)이 증가하였다. 2016년 1차 사업의 비트레포네마검사와 트레포네마검사의 결 과 회신율은 각각 $94.2 \%$ 와 $50.2 \%$ 였고, 2 차 사업의 회신율은 각각 $94.7 \%$ 와 $49.5 \%$ 였다. 2017 년 1차 사업의 회신율은 각 각 $94.2 \%$ 과 $49.5 \%$ 였고, 2 차 사업의 회신율은 각각 $92.8 \%$ 과 $48.7 \%$ 로 전 회차에 비하면 다소 낮으나 통계적으로 유의한 차 이는 없었다.

2016-2017년 감염성 세균항원항체검사 중 비트레포네마검 사는 RPR card 수기법을 사용하고 있는 기관이 약 $50 \%$ 정 도로 가장 많이 사용하고 있었으나, 2015년 사용률 65.9\%에 비해 유의하게 감소하였다(chi-square test, $P<0.0001)$ [1]. RPR TIA 자동화법을 사용하는 기관의 비율은 2016년 1차 사 업의 $29.5 \%$ 에서 2017 년 2차 사업의 $36.1 \%$ 로 유의하게 증가 하였다(chi-square test, $P<0.05$ ). 한편, 2016-2017년 감염성 세균항원항체검사 중 트레포네마검사는 TPPA를 사용하고 있 는 기관이 약 $40 \%$ 내외로 가장 많이 사용하고 있었고, CLIA 와 TPLA의 자동화법을 사용하는 기관의 비율은 각각 약 $15 \%$ 와 $17 \%$ 정도였다. ICA를 사용하는 기관은 2016년 1차 사업의 $13.8 \%$ 에서 2017년 2차 사업의 $21.6 \%$ 로 유의하게 증가하였다 (chi-square test, $P<0.05$ ).

2017년 1차 신빙도조사사업에서 음성 검체인 IB-17-02와 IB-17-03에서 비트레포네마검사가 각각 $92.5 \%$ 와 93.8\%의 정답률을 보였고, 트레포네마검사가 각각 $94.0 \%$ 와 $93.3 \%$ 의 정답률을 보였다. 이는 2016년 1차와 2차, 2017년 2차 사업의 정답률인 97.0\%-100.0\%에 비해 유의하게 낮았다(chi-square test, $P<0.0001)$. 특히 비트레포네마검사 중 RPR TIA법과 트레포네마검사 중 CLIA법에서 정답률이 약 $80 \%$ 로 다른 방
법에 비하여 유의하게 낮았다. 이는 일부 회사의 시약에서 나 타나는 현상으로 다수의 인체유래물 혈청을 모아 정도관리물 질을 제조하는 과정에서 나타나는 기질효과(matrix effect)가 그 원인으로 추정되었다[2-4]. 그 근거로 소수의 공여자 혈액 을 원료로 제조한 정도관리물질은 그런 현상이 잘 나타나지 않 았다. 따라서 신빙도조사에 사용되는 자가제조물질의 품질을 보장하기 위하여 다수보다는 소수의 인체유래물을 원료로 제 조하여야 하며 다양한 방법 및 시약 간 결과 일치도를 사전에 검토하는 것이 좋을 것이다.

\section{REFERENCES}

1. Cha YJ, Bae JH, Jung YS, Chae SL; Immunoserology Subcommittee, Korean Association of External Quality Assessment Service. Annual report on the external quality assessment scheme of viral markers and serological tests for syphilis in Korea (2015). J Lab Med Qual Assur 2016; 38:214-24.

2. Eckfeldt JH, Copeland KR. Accuracy verification and identification of matrix effects: the College of American Pathologists' protocol. Arch Pathol Lab Med 1993;117:3816.

3. Rej R. Proficiency testing, matrix effects, and method evaluation. Clin Chem 1994;40:345-6.

4. Miller WG, Jones GR, Horowitz GL, Weykamp C. Proficiency testing/external quality assessment: current challenges and future directions. Clin Chem 2011;57:1670-80. 